\title{
PENERAPAN DIVERSI TERHADAP ANAK YANG BERKONFLIK DENGAN HUKUM MENURUT QANUN ACEH NOMOR 9 TAHUN 2008 TENTANG PEMBINAAN KEHIDUPAN ADAT DAN ADAT ISTIADAT DAN UNDANG-UNDANG NOMOR 11 TAHUN 2012 TENTANG SISTEM PERADILAN PIDANA ANAK (Studi di Wilayah Hukum Pengadilan Negeri Langsa)
}

\author{
Maulana Muslim Hrp, Madiasa Ablisar, Marlina, Edy Ikhsan
}

Ilmu Hukum, Fakultas Hukum, Universitas Sumatera Utara

Jalan Dr. T. Mansur No.9, Padang Bulan, Kec. Medan Baru, Kota Medan, Sumatera Utara

maulanahrp49@gmail.com

\begin{abstract}
The background is by two law applications that apply in Aceh, the first law that generally applies in Indonesia and the second one that applies specifically in Aceh, the Law Number 11 of 2012 concerning the System J uvenile Criminal Court is a way out for better handling of children conflict with the law. The law regulates diversion where there are two important things that have a special place in the SPPA Law, namely restorative justice and diversion.

The results showed that the resolution of the problem of children conflict with the law in Aceh consists of two legal applications, starting with the mediation process according to Aceh Qanun Number 9 of 2008 concerning fostering customary life and customs Development with the aim that these problems can be resolved amicably according to the Decree J oint between the Governor of Aceh and the Aceh Regional Police and the Aceh Traditional Council No 189/677/2011 dated 20 December 2011 concerning the Implementation of the Gampong and Mukim Adat Courts, but if during the mediation process no agreement is found then proceed to the legal process according to the Law Number 11 of 2012 concerning the Criminal J ustice System for Children.
\end{abstract}

Keywords: Diversion, Qanun, Criminal J ustice System

\begin{abstract}
Abstrak
Dilatarbelakangi oleh adanya dua penerapan hukum yang berlaku di Aceh yaitu pertama hukum yang secara umum berlaku di Indonesia dan kedua hukum khusus yang berlaku di Aceh (Qanun), maka Undang-Undang Nomor 11 Tahun 2012 tentang Sistem Peradilan Pidana Anak menjadi jalan keluar untuk penanganan anak yang berkonflik dengan hukum secara lebih baik. Di dalam Undang- Undang tersebut mengatur tentang diversi dimana terdapat dua hal penting yang mendapat tempat istimewa dalam UU SPPA yaitu keadilan restoratif dan diversi. Hasil penelitian menunjukkan bahwa penyelesaian masalah anak yang berkonflik dengan hukum di provinsi Aceh terdiri dari dua penerapan hukum yaitu diawali dengan proses mediasi
\end{abstract}


Volume 16, Nomor 1, Januari - Juni 2021

\begin{abstract}
menurut Qanun Aceh Nomor 9 Tahun 2008 Tentang Pembinaan Keidupan Adat Dan Adat Istiadat dengan tujuan agar permasalaan tersebut dapat diselesaikan secara kekeluargaan sesuai Surat Keputusan Bersama (SKB) antara Gubernur Aceh dengan Kepolisian Daerah Aceh dan Majelis Adat Aceh No 189/677/2011 Tanggal 20 Desember 2011 tentang Penyelenggaraan Peradilan Adat Gampong dan Mukim, namun apabila saat proses mediasi tersebut tidak ditemukan kesepakatan maka dilanjutkan ke proses hukum sesuai Undangundang Nomor 11 Tahun 2012 Tentang Sistem Peradilan Pidana Anak.
\end{abstract}

KataKunci: Diversi, Qanun, SPPA

\title{
Pendahuluan
}

Negara Kesatuan Republik Indonesia adalah Negara yang berlandaskan atas hukum (Rechtstaat) dan bukan berdasar atas kekuasaan semata. ${ }^{1}$ Negara Hukum adalah negara berlandaskan atas hukum dan keadilan bagi warganya. Artinya adalah segala kewenangan dan tindakan alat-alat perlengkapan negara atau penguasa, semata-mata berdasarkan hukum atau dengan kata lain diatur oleh hukum sehingga dapat mencerminkan keadilan bagi pergaulan hidup warganya. ${ }^{2}$

Mempersiapkan generasi muda yang akan memimpin bangsa dan negara diperlukan pembinaan dan perlindungan hak-hak dan kewajiban bagi anak-anak dimana anak adalah amanah sekaligus karunia tuhan yang maha esa yang senantiasa harus dijaga, karena di dalam dirinya melekat harkat, martabat dan hak-hak sebagai manusia yang harus dijunjung tinggi. Hak asasi Anak merupakan bagian dari Hak Asasi Manusia yang termuat dalam Undang-Undang Dasar 1945 dan konfensi perserikatan bangsa-bangsa dalam hak-hak anak. Upaya untuk perlindungan anak perlu dilaksanakan sedini mungkin yakni sejak dari janin dalam kandungan sampai dengan umur 18 tahun.

Adanya Undang-Undang Nomor 11 Tahun 2012 tentang Sistem Peradilan Pidana Anak dan Qanun Aceh No 9 Tahun 2008 tentang Pembinaan Kehidupan Adat dan Adat Istiadat menjadi jalan keluar untuk penanganan anak yang berkonflik dengan hukum secara lebih baik.

Dengan adanya dua penerapan hukum yang berlaku di Aceh yaitu pertama hukum yang secara umum berlaku di Indonesia dan kedua hukum khusus yang berlaku di Aceh (Qanun) sehingga penulis tertarik untuk melakukan penelitian di wilayah hukum Pengadilan Negeri Langsa dikarenakan di wilayah hukum tersebut banyak dijumpai tindak kejahatan yang dilakukan oleh anak-anak, hal itu sesuai dengan data 3 (tiga) tahun terakhir sebagai berikut:

1 Akil Mochtar, Pembalikan Beban Pembuktian Tindak Pidana Korupsi, (Jakarta: Mahkamah Konstitusi, 2009), hlm 18

2 Abdul Aziz Hakim, Negara Hukum dan Demokrasi Di Indonesia, (Yogyakarta: Pustaka Pelajar, 2011, hlm 8 
Tabel 1

Angka kejahatan anak yang berkonflik dengan hukum di Pengadilan Negeri Langsa

\begin{tabular}{|r|l|c|c|c|}
\hline \multirow{2}{*}{ No } & \multirow{2}{*}{ Jenis Perkara } & \multicolumn{3}{|c|}{ Tahun } \\
\cline { 3 - 5 } & & 2018 & 2019 & 2020 \\
\hline 1 & Narkotika & 2 & 2 & 3 \\
\hline 2 & Pencurian & 4 & 3 & 1 \\
\hline 3 & $\begin{array}{l}\text { Kecelakaan Mengakibatkan } \\
\text { Kematian }\end{array}$ & - & 1 & - \\
\hline 4 & $\begin{array}{l}\text { Penipuan } \\
\text { Jumlah }\end{array}$ & 1 & - & - \\
\hline \multicolumn{2}{|r}{} & 7 & 6 & 4 \\
\hline
\end{tabular}

\section{Rumusan Masalah}

Berdasarkan uraian yang telah dibahas dalam pendahuluan di atas, maka penulis dalam menganalisis permasalahan dalam penelitian ini adalah bagaimana penyelesaian terhadap anak yang berkonflik dengan hukum menurut Qanun Nomor 9 Tahun 2008 tentang pembinaan kehidupan adat dan adat istiadat serta Undang-undang No 11 Tahun 2012 Tentang Sistem Peradilan Pidana Anak.

\section{Tinjauan Pustaka}

\section{a. Teori Kearifan Lokal}

Teori Kearifan lokal menurut $\mathrm{C}$ van Vollenhoven adalah Nilai-nilai, norma, hukum-hukum dan pengetahuan yang dibentuk oleh ajaran agama, kepercayaankepercayaan, tata nilai tradisional dan pengalaman pengalaman yang diwariskan oleh leluhur yang akhirnya membentuk sistem pengetahuan lokal yang digunakan untuk memecahkan permasalahan-permasalahan sehari- hari oleh masyarakat. ${ }^{3}$

Dalam bahasa asing sering juga dikonsepsikan sebagai kebijakan setempat local wisdom atau pengetahuan setempat "local knowledge" atau kecerdasan setempat local genious. Berbagai strategi dilakukan oleh masyarakat setempat untuk menjaga kebudayaannya.

Eksistensi hukum adat di Indonesia sampai saat ini telah diakui secara konstitusional. Sebagaimana tertuang dalam Pasal 18 B ayat (2) Undang-Undang

3 Ulfah Fajarini, Peranan Kearifan Lokal dalam Pendidikan Karakter, (Jakarta: Rineka Cipta, 2014), hlm 123 
Dasar 1945 yang menyatakan bahwa "Negara mengakui dan menghormati kesatuankesatuan masyarakat hukum adat beserta hak-hak tradisionalnya sepanjang masih hidup dan sesuai dengan perkembangan dan prinsip Negara Kesatuan Republik Indonesia yang diatur dalam undang-undang". Selanjutnya dalam Pasal 28 I ayat (3) UndangUndang Dasar 1945 dinyatakan bahwa identitas budaya dan hak masyarakat tradisional dihormati selaras dengan perkembangan jaman dan peradaban.

Dalam berbagai undang-undang juga disinggung memgenai eksistensi hukum adat dan masyarakat adat. Apabila ditelusuri lebih lanjut, hukum adat dalam prakteknya adalah berisi kearifan-kearian lokal yang saat ini sedang mengemuka karena kapasitasnya telah terbukti bermanfaat sebagai pendekatan dalam berbagai aspek kehidupan. Secara yuridis formal kearifan lokal telah diperkenalkan di dalam Qanun Aceh Nomor 9 Tahun 2008 Tentang Pembinaan Kehidupan Adat dan Adat Istiadat dalam upaya penyelesaian sengketa/perselisihan di gampong dengan memperhatikan nilai-nilai luhur yang berlaku dalam tata kehidupan masyarakat.

\section{b. Teori Penegakan Hukum}

Teori penegakan hukum menurut Lawrence M Friedman, seorang ahli sosiologi hukum dari Amerika, ada tiga elemen utama dalam penegakan hukum , yaitu:

a) Struktur hukum (Legal Structure)

b) Subtansi hukum (Legal Substance)

c) Budaya hukum (Legal Culture)

Menurut Lawrence berhasil atau tidaknya penegakan hukum bergantung pada: Substansi Hukum, Struktur Hukum/Pranata Hukum dan Budaya Hukum.

Pertama, substansi hukum; dalam teori Lawrence hal ini disebut sebagai sistem substansial yang menentukan dapat atau tidaknya hukum itu dilaksanakan. Substansi juga berarti produk yang dihasilkan oleh orang yang berada dalam sistem hukum yang mencakup keputusan yang mereka keluarkan, aturan baru yang mereka rancang. Substansi juga mencakup hukum yang hidup dalam masyarakat (living law), bukan hanya aturan yang ada dalam kitab undang-undang (law books).

Sebagai negara yang masih menganut Civil Law Sistem atau sistem Eropa Kontinental meski sebagian peraturan perundang-undangan juga telah menganut Common Law Sistem atau Anglo Saxon dikatakan hukum adalah peraturan-peraturan yang tertulis sedangkan peraturan-peraturan yang tidak tertulis bukan dinyatakan hukum. Sistem ini mempengaruhi sistem hukum di Indonesia.

Salah satu pengaruhnya adalah adanya asas legalitas dalam KUHP. Dalam pasal 1 KUHP ditentukan "tidak ada suatu perbuatan pidana yang dapat di hukum jika tidak ada aturan yang mengaturnya". Sehingga dapat atau tidaknya suatu perbuatan dikenakan sanksi hukum apabila perbuatan tersebut telah mendapatkan pengaturannya dalam peraturan perundang-undangan. 
Kedua, Struktur hukum/pranata hukum; dalam hal ini disebut sebagai sistem struktural yang menentukan dapat atau tidaknya hukum itu dilaksanakan dengan baik. Struktur hukum berdasarkan UU No. 8 Tahun 1981 meliputi; mulai dari kepolisian, Kejaksaan, Pengadilan dan Badan Pelaksana Pidana (LAPAS). Kewenangan lembaga penegakan hukum dijamin oleh undang-undang, sehingga dalam melaksanakan tugas dan tanggung jawab terlepas dari pengaruh kekuasaan pemerintah dan pengaruh-pengaruh lain.

Ketiga, Budaya hukum; Budaya hukum adalah unsur dari sistem hukum yang paling sulit untuk dibentuk karena membutuhkan jangka waktu relatif panjang. Hal ini terjadi karena budaya berkaitan dengan nilai-nilai. Apa yang berkaitan dengan nilai, pasti membutuhkan proses internalisasi agar nilai-nilai itu tidak sekadar diketahui, tetapi juga dipraktikkan dalam kehidupan sehari-hari.

Lawrence Meil Friedman memiliki anekdot yang menarik tentang hal ini, "Without legal culture, the legal system is iner-a dead fish lying in a basket, not a living fish swimming in its sea." ${ }^{4}$ Hukum di negara ini niscaya tak berdaya, ibarat ikan mati, jika tak disokong oleh budaya hukum bangsa sendiri. Hukum adalah untuk manusia, ${ }^{5}$ artinya suatu aturan hukum tidak dapat dilepas dari aspek manusia. Bahkan ia berpusat pada manusia karena esensi dan eksistensinya berpusat pada manusia (antro posentris), dari, oleh, dan untuk manusia.

Terdapat adegium yang menyatakan "fiat justitia pereat mundus" (meskipun langit runtuh, hukum harus ditegakkan). Hukum tidak dapat berjalan atau tegak bila tidak ada aparat penegak hukum yang kredibilitas, kompeten, dan independen. Seberapa bagusnya suatu peraturan perundang-undangan bila tidak didukung dengan aparat penegak hukum yang baik maka keadilan hanya angan-angan.

Lemahnya mentalitas aparat penegak hukum mengakibatkan penegakan hukum tidak berjalan sebagaimana mestinya. Banyak faktor yang mempengaruhi lemahnya mentalitas aparat penegak hukum diantaranya lemahnya pemahaman Agama, Ekonomi, proses rekrutmen yang tidak transparan dan lain sebagainya. Sehingga dapat dipertegas bahwa faktor penegak hukum memainkan peran penting dalam memfungsikan hukum.

Peraturan sudah baik yang diharapkan, tetapi kualitas penegak hukum rendah maka akan ada masalah. Demikian juga, apabila peraturannya buruk sedangkan kualitas penegak hukum baik, kemungkinan munculnya masalah masih terbuka. ${ }^{6}$

4 Lawrence Meil Friedman, Law and Society; an Introductions, (Prencite-Hall Foundations of Modern Sociology Series, Englewood Cliffts), (New Jersey: Standford University, 1979), hlm 7

5 Satjipto Raharjo, Membedah hukum progresif, (Jakarta: Buku Kompas, 2007), hlm 151

6 W. Friedman, Teori dan Filsafat Hukum: Telaah kritis atasi Teori-teori Hukum (susunan I), judul asli Legal Theory, penerjemah: Muhammad Arifin, Cetakan ke-2, (Jakarta: PT Raja Grafindo Persada, 1993), hlm 20 
Oleh karena itu dalam menciptakan penegakan hukum yang baik harus memiliki subtansi hukum yang baik, penegak hukum yang baik dan budaya hukum yang baik.

\section{Hasil Penelitian dan Pembahasan}

\section{A. Penyelesaian Terhadap Anak Yang Berkonflik Dengan Hukum Menurut Qanun Aceh Nomor 9 Tahun 2008 Tentang Pembinaan Kehidupan Adat dan Adat Istiadat}

Berdasarkan Pasal 1 angka (3) Undang-Undang Nomor 11 tahun 2012 Tentang Sistem Peradilan Pidana Anak yang dimaksud dengan anak yang berkonflik dengan hukum adalah anak yang telah berumur 12 (dua belas) tahun, tetapi belum berumur 18 (delapan belas) tahun yang diduga melakukan tindak pidana. Masalah anak merupakan arus balik yang tidak diperhitungkan dari proses dan perkembangan pembangunan bangsa-bangsa yang mempunyai cita-cita tinggi dan masa depan cemerlang guna menyongsong dan menggantikan pemimpin-pemimpin bangsa Indonesia. Terkait dengan hal itu paradigma pembangunan haruslah pro anak. ${ }^{7}$

Menurut Apong Herlina, anak yang berkonflik dengan hukum dapat juga dikatakan sebagai anak yang terpaksa berkonflik dengan sistem pengadilan pidana karena: ${ }^{8}$

a. Disangka, didakwa, atau dinyatakan terbukti bersalah melanggar hukum; atau

b. Telah menjadi korban akibat perbuatan pelanggran hukum dilakukan orang/kelompok orang/lembaga/Negara terhadapnya; atau

c. Telah melihat, mendengar, merasakan atau mengetahui suatu peristiwa pelanggaran hukum.

Anak sebagai pelaku atau anak yang berkonflik dengan hukum adalah anak yang disangka, didakwa, atau dinyatakan terbukti bersalah melanggar hukum dan memerlukan perlindungan.

Kategori anak sebagai pelaku tindak pidana tentu saja memiliki ketentuan umur tersendiri. Mereka adalah anak yang telah berumur 12 (dua belas) tahun, tetapi belum berumur 18 (delapan belas) tahun yang diduga melakukan tindak pidana. Jadi anak yang berumur di bawah 12 tahun, walaupun melakukan tindak pidana, belum dikategorikan sebagai anak yang berkonflik dengan hukum. Dengan demikian, ia berada di luar ketentuan ini. Begitu juga, orang yang telah berumur di atas 18 tahun tidak lagi

\footnotetext{
7 Muhammad Joni dan Zulchaina Z Tanamas, Aspek Perlindungan Anak DalamPerspektif Konvensi Hak Anak, (Bandung: PT Citra Aditya Bakti, 1999), hlm 83

8 Apong Herlina, dkk, Perlindungan Terhadap Anak Yang Berhadapan Dengan Hukum, Buku Saku Untuk Polisi, (Jakarta: Unicef, 2014), hlm 17
} 
digolongkan kepada anak, namun sudah dianggap dewasa, dan berlaku ketentuan umum hukum pidana.

Kategori anak yang menjadi korban tindak pidana adalah anak yang belum berusia 18 tahun. Sedangkan kategori anak yang juga belum berumur 18 tahun. Untuk kategori anak sebagai korban dan anak sebagai saksi disamakan usianya, yaitu 18 tahun. Di sini tidak diberi batasan apakah anak di bawah usia 12 tahun disebut korban dan menjadi saksi, Kalau melihat isi ketentuan ini tentu saja harus dipahami bahwa anak yang belum berumur 12 dapat menjadi korban dan dapat pula sebagai saksi.

Sehubungan dengan dibentuknya Dinas Syariah Islam dan Wilayatul Hisbah di Aceh diharapkan dapat menurunkan angka anak yang berkonflik dengan hukum di Aceh, dinas syariat islam sebagai lembaga pemerintah yang yang memegang peran untuk melaksanakan penegakkan Syariat Islam secara kaffah di Aceh khususnya Kota Langsa yang memiliki peran sebagai lembaga pengawasan terhadap pelaksanaan Syariat Islam di Kota langsa yang dilaksanakan bersama dengan Wilayatul Hisbah Kota Langsa.

Dalam mengatasi pelanggaran dan kejahatan di Kota langsa, tentunya Dinas Syariat Islam mempunyai berbagai upaya yang dilakukan dalam mengatasinya, adapun upaya-upaya yang dilakukan oleh Dinas Syariat Islam dan Wilayatul Hisbah, yaitu: ${ }^{9}$

1) Meningkatkan wawasan dan kesadaran anak melalui pembinaan di lingkungan sekolah.

2) Meningkatkan kesadaran dan partisipasi masyarakat.

3) Meningkatkan pengawasan pada daerah-daerah yang rawan.

4) Berkordinasi dengan Diskominfo.

Oleh karena itu, dengan upaya-upaya tersebut maka tingkat kejahatan dan kriminalitas yang dilakukan anak di Kota Langsa terhitung rendah dan dapat diminimalisir.

Dalam penyelenggaraan peradilan adat di gampong, Gampong diberi kewenangan dalam menyelesaikan sengketa/perselisihan berdasarkan Undang-Undang Nomor 11 Tahun 2006 Tentang Pemerintahan Aceh, PERDA Nomor 7 Tahun 2000 Tentang Penyelenggaraan Kehidupan Adat, dan SKB (Surat Keputusan Bersama) antara Gubernur, Kapolda, dan Majelis Adat Aceh No 189/677/2011 Tanggal 20 Desember 2011 tentang Penyelenggaraan Peradilan Adat Gampong dan Mukim.

Dalam perkembangannya, khususnya menyangkut tentang pelaksanaan Peradilan Adat di Aceh, meskipun tidak dijumpai nama-nama peradilan adat secara khusus dalam penyelesaian di gampong-gampong pada kenyataannya masyarakat Aceh masih terus menerapkan dan mempertahankan hukum adat dalam hal penyelesaian persoalan adat atau delik.

9 Hasil Wawancara dengan Bapak Aji Usmanuddin Kepala Dinas Syariat Islam Kota Langsa Tanggal 10 Desember 2020 
Dalam menjalankan peradilan adat di gampong, telah ditentukan bahwa salah satu tugas dan fungsi geuchik adalah sebagai hakim gampong yang berupaya menyelesaikan permasalahan hukum terkait sengketa/perselisihan yang terjadi di dalam gampong ${ }^{10}$ dibantu oleh Sekretaris Gampong, Ulee Jurong (kepala lorong), Ulama, Cendikiawan, Tokoh Adat, Tuha Peuet (unsur pemerintahan gampong yang berfungsi sebagai badan permusyawaratan gampong) ${ }^{11}$ dan Imeum Meunasah (orang yang memimpin kegiatan-kegiatan masyarakat di gampong yang berkenaan dengan bidang agama Islam, pelaksanaan dan penegakan syari'at Islam) ${ }^{12}$.

Mekanisme penyelesaian sengketa/perselisihan di gampong sesuai dengan adat dan adat istiadat sebagaimana dimaksud di atas diselesaikan secara bertahap (Pasal 13 ayat 2). Maksudnya sedapat mungkin perkara-perkara yang tercantum dalam Qanun Aceh Nomor 9 Tahun 2008 tentang Pembinaan Kehidupan Adat dan Adat Istiadat Pasal 13 diselesaikan terlebih dahulu pada tingkat peradilan gampong oleh aparat gampong. Dimana terhadap jenis perkara di atas tidak langsung dibawa keluar gampong untuk menyelesaikannya, baik oleh polisi atau oleh pihak lainnya. Bahkan, dalam ayat berikutnya ditegaskan lagi, bahwa aparat penegak hukum memberikan kesempatan agar sengketa/perselisihan diselesaikan terlebih dahulu secara adat di gampong.

Seperti halnya tindak kejahatan yang dilakukan oleh anak di bawah umur, dan merupakan tindak kejahatan yang nasih tergolong ringan maka proses penyelesaiannya akan terlebih dahulu dilakukan oleh geuchik beserta perangkat gampong yang merupakan lembaga adat agar jalan damai bisa ditempuh, sehingga tidak perlu untuk dilanjutkan ke jalur hukum.

Dalam Pasal 15 Qanun Aceh Nomor 9 Tahun 2008, ditentukan bahwa "tata cara dan syarat-syarat penyelesaian perselisihan/persengketaan, dilaksanakan sesuai dengan ketentuan adat setempat". Walaupun ketentuan ini sangat singkat dan tegas, namun maknanya sangat dalam dan luas. Ini merupakan salah satu khas lainnya (disamping bersifat communal) dari hukum adat yang bersifat fleksibilitas.

Khusus terhadap peradilan adat dalam perkara tindak pidana ringan yang dilakukan oleh anak, tahapan penyelesaian perkara adalah sebagai berikut:

a. Pelaporan yang dilakukan oleh pihak korban atau kedua belah pihak kepada kepala Jurong tempat dimana peristiwa hukum tersebut terjadi

b. Adakalannya kepala jurong itu sendiri yang menyelesaikannyan, jika kasusnya tidak serius. Namun jika kasus tersebut serius dan rumit dan melibatkan kepentingan umum, maka kepala jurong melaporkan ke keuchik.

c. Segera setelah Keuchik menerima laporan laporan dari kepala Jurong atau dari pihak korban, maka keuchik membuat rapat internal dengan sekretaris menentukan

${ }^{10}$ Pasal 15 ayat (1) huruf j dan k Qanun Aceh Nomor 10 Tahun 2008 Tentang Lembaga Adat

11 Pasal 1 angka 18 Qanun Aceh Nomor 10 Tahun 2008 Tentang Lembaga Adat

12 Pasal 1 angka 21 Qanun Aceh Nomor 10 Tahun 2008 Tentang Lembaga Adat 
jadwal sidang. Pelaporan tersebut tidak boleh dilakukan di sembarang tempat seperti warung kopi, pasar, tetapi harus dilakukan ditempat tertutup seperti di rumah atau di meunasah.

d. Sebelum persidangan digelar, Keuchik dan perangkatnya (sekretaris keuchik atau sekretaris Gampong, imuem meunasah, dan para kepala jurong) melakukan pendekatan terhadap kedua belah pihak, pendekatan tersebut bertujuanuntuk mengetahui duduk perkara yang sebenarnya dan sekaligus menanyakan kesediaan mereka untuk diselesaikan secara damai. Pada saat pendekatan tersebut, para pelaksana peradilan adat akan menggunakan berbagai metode mediasi dan negosiasi, sehingga kasus itu dapat serta diselesaikan.

e. Pendekatan tidak hanya dilakukan oleh keuchik dan perangkatnya, tetapi dapat juga dilakukan oleh siapa saja yang dirasa dekat dan disegani oleh para pihak. Untuk kasus yang korbannya orang perempuan atau kaum muda, maka pendekatan biasanya dilakukan oleh istri keuchik atau anggota Tuha Peut yang perempuan lainnya dirasa dekat dengan korban atau kedua belah pihak.

f. Jika kesepakatan penyelesaian secara damai telah disetujui oleh kedua belah pihak, maka sekretaris keuchik akan mengundang secara resmi kedua belah pihak untuk mengahdiri persidangan pada hari dan tanggal yang telah ditetapkan.

g. Pada saat persidangan berlangsung, para pihak dapat diwakili oleh walinya atau saudarannya yang lain sebagai juru bicara.

h. Persidangan bersifat resmi dan terbuka untuk kasus besar, yang biasanya digelar di meunasah atau tempat-tempat lain yang dianggap netral bagi kedua belah pihak. ${ }^{13}$

Waktu yang dibutuhkan dalam penyelesaian tidak boleh lebih dari 9 hari. putusan harus adil bagi kedua belah pihak. Apabila dalam batas waktu yang ditentukan keuchik sebagai kepala gampong tidak menindak lanjuti perkara, maka para pihak yang berselisih diperbolehkan untuk menempuh jalur hukum formal.

\section{B. Keunggulan Penerapan Diversi Menurut Qanun Aceh Nomor 9 Tahun 2008 Tentang Pembinaan Kehidupan Adat dan Adat Istiadat dibandingkan dengan Undang-Undang No 11 Tahun 2012 Tentang Sistem Peradilan Pidana Anak}

Musyawarah sebagai cara sederhana dalam penyelesaian suatu permasalahan yang menyangkut kepentingan beberapa pihak dilakukan melalui proses duduk bersama secara damai diantara pihak-pihak untuk mencapai kata sepakat denan tidak salin merugikan dan untuk menghindarkan perpecahan diantara mereka. Metode musyawarah

13 Isnatul Rahmi dan Riza nizarli, Penerapan Restorative Justice Dalam Penyelesaian Tindak Pidana Pencurian Oleh Anak dalam Perspektif Adat Aceh, Syiah Kuala Law Jurnal, Vol.4 (1) April 2020, hlm 14-15 
ini sudah menjadi adat/kebiasaan di masyarakat yan biasa dilakukan setiap menghadapi permasalahan-permasalahan menyangkut kepentingan bersama tanpa melalui prosedur atau tata cara formal.

Hasil keputusan dari proses musyawarah mufakat ini akan ditaati oleh semua pihak dan mampu menampung kepentingan semua pihak serta mampu menampung kepentingan semua pihak serta mampu memberikan rasa keadilan secara seimbang, dan dapat dirasakan secara bersama-sama.

Selain itu terdapat banyak keunggulan penerapan diversi dan penyelesaian masalah secara adat yaitu sebagai berikut :

1. Terpercaya atau Amanah (Acceptability)

Peradilan adat dapat dipercaya oleh masyarakat.

2. Tanggung Jawab/Akuntabilitas (Accountability)

Prinsip ini menggarisbawahi pertanggung jawaban dari para pelaksana peradilan adat dalam menyelesaikan perkara tidak hanya ditujukan kepada para pihak, masyarakat dan negara tetapi juga kepada Allah SWT.

3. Kesetaraan di Depan Hukum/Non-diskriminasi (Equality Before The Law/Non Discriminaton)

Peradilan adat tidak boleh membeda-bedakan jenis kelamin, status sosial ataupun umur. Semua orang mempunyai kedudukan dan hak yang sama dihadapan adat.

4. Cepat, Mudah dan Murah (Accessibillity to all Citizens)

Setiap putusan peradilan Gampong harus dapat dijangkau oleh masyarakatbaik yang menyangkut dengan biaya, waktu dan prosedurnya.

5. Ikhlas dan Sukarela (Voluntary Nature)

Keadilan adat tidak boleh memaksa para pihak untuk menyelesaikan perkaranya melalui peradilan adat.

6. Penyelesaian Damai/ kerukunan (Peaceful Resolution)

Dalam bahasa Aceh, azas ini dikenal dengan ungkapan "Uleue bak mate ranteng ek patah", tujuan dari peradilan adat adalah untuk menciptakan keseimbangan dan kedamaian dalam masyarakat.

7. Musyawarah/Mufakat (Consensus)

Keputusan yang dibuat dalam peradilan adat berdasarkan hasil musyawarah mufakat yang berlandaskan hukum dari para pelaksana peradilan adat.

8. Keterbukaan untuk Umum (Transparency) 
Volume 16, Nomor 1, Januari - Juni 2021

Semua proses peradilan (kecuali untuk kasus-kasus tertentu) baik yang menyangkut pautkan penerimaan pengaduan, pemanggilan saksi, persidangan maupun pengambilan sertapembacaan putusan harus dijalankan secara terbuka.

9. Jujur dan Kompetensi (Competence/Authority)

Seorang pemimpin adat tidak boleh mengambil keuntungan dalam bentuk apapun baik material maupun non material dari penanganan perkara.

10. Keberagaman (Pluralisme)

Peradilan adat menghargai keberagaman peraturan hukum yang terdiri dari berbagai sistem hukum adat dan berlaku dalam suatu masyarakat adat tertentu.

11. Praduga Tak Bersalah (Presumption of Innocence)

Hukum adat tidak membenarkan adanya tindakan main hakim sendiri.

12. Berkeadilan (Proportional Justice)

Putusan peradilan adat harus bersifat adil dan diterapkan berpedoman sesuai dengan berdasarkan parahnya perkara dan keadaan ekonomi para pihak. ${ }^{14}$

\section{Penerapan Diversi Terhadap Anak Yang Berkonflik Dengan Hukum di Pengadilan Negeri Langsa}

Penegakan hukum adalah proses dilakukannya upaya untuk tegaknya atau berfungsinya norma-norma hukum secara nyata sebagai pedoman prilaku dalam lalu lintas atau hubungan-hubungan hukum yang berhubungan dengan masyarakat dan bernegara. ${ }^{15}$

Dalam penegakan hukum mengandung tiga unsur, pertama kepastian hukum (rechtssicherheit), yang berarti bagaimana hukumnya itulah yang harus berlaku dan tidak boleh menyimpang, hukum harus dapat menciptakan kepastian hukum karena hukum bertujuan untuk ketertiban masyarakat. Kedua kemanfaatan (zweekmassigkeit), karena hukum untuk manusia maka pelaksanaan hukum atau penegakan hukum harus memberi manfaat atau kegunaan bagi masyarakat, jangan sampai justru karena hukumnya diterapkan menimbulkan keresahan masyarakat. Ketiga keadilan (gerechtigheit), bahwa dalam pelaksanaan hukum atau penegakan hukum harus adil karena hukum bersifat umum dan berlaku bagi setiap orang dan bersifat menyamaratakan. Tetapi hukum tidak

\footnotetext{
${ }_{14}$ Majelis Adat Aceh, Pedoman Peradilan Adat di Aceh Untuk Peradilan Adat Yang Adil dan Akuntabel, 2008, hlm 5

15 Jimly Asshiddiqie, Penegakan Hukum, hlm 1, diakses melalui www.jimly.com/makalah/namafile/56/Penegakan_Hukum.pdf, pada tanggal 22 November 2020, pukul 01.22 WIB
} 
identik dengan keadilan karena keadilan bersifat subyektif, individualistik dan tidak menyamaratakan. ${ }^{16}$

Penegakan hukum dipengaruhi oleh beberapa faktor diantaranya adalah:

1) Faktor hukum.

2) Faktor penegak hukum

3) Faktor sarana atau fasilitas

4) Faktor masyarakat

5) Faktor kebudayaan ${ }^{17}$

Kelima faktor di atas saling berkaitan karena menjadi hal pokok dalam penegakan hukum, dan sebagai tolak ukur dari efektivitas penegakan hukum. Dari lima faktor penegakan hukum tersebut faktor penegak hukumnya sendiri merupakan titik sentralnya.

a. Hal-hal Yang Mendukung Penerapan Restorative Justice Sebagai Bentuk Penyelesaian Tindak Pidana Yang Dilakukan Oleh anak

Hal-hal yang diperlukan untuk mendukung penerapan restorative justice sebagai bentuk penyelesaian tindak pidana yang dilakukan oleh anak adalah sebagai berikut :

a. Pelaku

1) Usia Pelaku Anak

2) Pengakuan dan Penyesalan Pelaku

3) Kondisi Anak sebagai Pelaku dan Jumlah Tindak Pidana yang Dilakukan Anak

b. Kategori Tindak Pidana

Kategori tindak pidana yang diancam dengan sanksi pidana sampai dengan 1 (satu) tahun harus diprioritaskan untuk dilakukan diskresi. Perkara tersebut tidak perlu diproses melalui hukum formal, cukup diberikan peringatan secara lisan maupun tertulis. Kategori tindak pidana yang diancam dengan sanksi pidana lebih dari 1 (satu) tahun dan sampai dengan dibawah 7 (tujuh) tahun dan bukan merupakan pengulangan tindak pidana diprioritaskan untuk diselesaikan dengan pendekatan keadilan restoratif, dengan cara mediasi atau musyawarah keluarga dengan melibatkan korban, pelaku dan keluarganya.

c. Korban

1) Dampak perbuatan terhadap korban

${ }^{16}$ Sudikno Mertokusumo, Mengenal Hukum, (Yogyakarta: Liberty, 2005), hlm 161

${ }^{17}$ Soerjono Soekanto, Faktor-faktor Yang Mempengaruhi Penegakan Hukum, (Jakarta: Raja Grafindo Persada, 2007), hlm 5 
2) Persetujuan korban

3) Partisipasi dan pendapat korban

d. Dukungan Orang Tua/Wali dan Keluarga

Orang tua/wali atau keluarga anak tersebut perlu dilibatkan secara aktif dalam penyelesaian perkara, program rehabilitasi, dan reintegrasi. Jika keluarga (orang tua/wali) tidak diikutsertakan secara aktif, maka rencana penyelesaian dengan pendekatan keadilan restoratif yang efektif akan sulit untuk diimplementasikan. Jika ada orang tua atau keluarga seperti ini maka APH atau pihak terkait wajib memberi pengertian kepada orang tua atau keluarga tersebut tentang perlunya dukungan keluarga.

e. Jenis-jenis penanganan dengan pendekatan keadilan restoratif

1) Mediasi korban dengan pelaku

2) Musyawarah Keluarga

3) Musyawarah Masyarakat. ${ }^{18}$

Selama proses keadilan restoratif berlangsung dan setelah keadilan restoratif dilaksanakan, pembimbing kemasyarakatan wajib melakukan pembimbingan dan pengawasan. Dalam hal kesepakatan keadilan restoratif tidak dilaksanakan dalam waktu yang ditentukan dalam kesepakatan, pembimbing kemasyarakatan segera melaporkan kepada pejabat yang bertanggung jawab.

Secara nasional dikehendaki bahwa tujuan penyelenggaraan sistem peradilan pidana anak, mengutamakan pada tujuan untuk kesejahteraan anak. Di Aceh khususnya Kota Langsa sendiri apabila terjadi tindak pidana yang dilakukan oleh anak dibawah umur akan selalu dilakukan upaya diversi dengan pertimbangan hukum untuk mengakomodir perdamaian antara korban dan pelaku yang cenderung didasari oleh tujuan dan asas hukum serta sosiologis hukum, dan tujuan hukum yang dimaksud adalah untuk memuat idee des recht yang meliputi tiga unsur keadilan (gerechtigkeit), kepastian (rechtsicherheit) dan kemanfaatan (zwechtmassgkeit), maka yang menjadi pertimbangan lebih kepada kemanfaatan hukum, tanpa mengenyampingkan rasa keadilan dan kepastian hukum itu sendiri.

Adapun proses diversi yang dilakukan adalah dengan mempertemukan antara korban dan pelaku serta melibatkan berbagai pihak seperti Bapas, tokoh-tokoh adat, Geuchik Gampong yang berada di tempat tinggal korban dan pelaku dan Hakim Pengadilan Negeri Langsa itu sendiri sebagai fasilitator dan mediator. Dalam proses ini mediator tidak mengarahkan, akan tetapi membantu para pihak untuk merumuskan tujuan sehingga keinginan pemecahan masalah dan bentuk penyelesaian benar-benar murni dari

18 M. Taufik Makarao, Pengkajian Hukum Tentang Penerapan Restorative Justice Dalam Penyelesaian Tindak Pidana yang Dilakukan Oleh Anak-Anak, (Jakarta: Badan Pembinaan Hukum Nasional Kementerian Hukum Dan HAM RI, 2013), hlm 114 
Volume 16, Nomor 1, Januari - Juni 2021

kedua belah pihak. Pihak ketiga tidak mendikte dan memaksa para pihak untuk memilih bentuk penyelesaian. Dengan demikian tujuan keadilan bagi kedua belah pihak diharapkan akan benar-benar tercapai.

Pada hakikatnya sistem peradilan pidana anak harus ditujukan untuk melindungi hak-hak dan kepentingan anak. Atas dasar hal tersebut dapat dikatakan bahwa proses peradilan pidana anak untuk penjatuhan pidana adalah ultimum remedium, tujuan proses peradilan pidana anak bukanlah ditujukan pada penghukuman, melainkan perbaikan kondisi, pemeliharaan dan perlindungan anak serta pencegahan pengurangan tindakan pengadilan yang konstruktif. ${ }^{19}$

Berdasarkan hasil wawancara penulis dengan Bapak Kurniawan selaku Hakim Khusus Anak di Pengadilan Negeri Langsa mengatakan bahwa :

"Untuk tindak pidana anak di daerah kota Langsa sendiri kebanyakan bukan tindak pidana berat, maka dari itu penerapan diversi dalam penyelesaian tindak pidana anak di kota Langsa sudah berjalan sesuai Undang Undang sistem peradilan pidana anak, apalagi di Aceh kebanyakan masyarakatnya juga sangat mengikuti adat budaya yang ada, dimana tidak semua masalah diselesaikan dengan hukum melainkan diselesaikan dulu secara musyawarah dengan melibatkan kepala-kepala adat, Dikarenakan para pihak yaitu korban dan pelaku menyetujui kesepakatan berupa penggantian kerugian yang timbul dari perbuatan pelaku. Akan tetapi pengadilan bukanlah satu-satunya institusi dalam menyelesaikan konflik, karena pihak-pihak yang berkonflik tidak selamanya menggunakan mekanisme penyelesaian pada badan peradilan" ${ }^{20}$.

Substansi yang mendasar dari sistem peradilan pidana anak adalah diversi yang mempunyai prinsip utama yaitu sebagai tindakan persuasif atau pendekatan dan pemberian kesempatan kepada pelaku untuk berubah dan mengajak pelaku untuk bertanggungjawab terhadap perbuatan yang dilakukannya.

\section{Penutup}

\section{A. Kesimpulan}

Penyelesaian terhadap anak yang berkonflik dengan hukum menurut Qanun Aceh Nomor 9 Tahun 2008 tentang Pembinaan Kehidupan Adat dan Adat Istiadat serta Qanun Aceh Nomor 10 tahun 2008 tentang Lembaga Adat yang mana di dalam hukum adat Aceh penyelesaian suatu masalah menggunakan konsep Restorative justice atau yang lebih dikenal dengan sebutan musyawarah guna mewujudkan

\footnotetext{
${ }^{19}$ Dwidja Priyatno, Wajah Hukum Pidana Asas dan Perkembangan, (Bekasi: Gramata Publishing, 2012), hlm 308

${ }^{20}$ Hasil Wawancara dengan Bapak Kurniawan Hakim Anak di Pengadilan Negeri Langsa Tanggal 10 Agustus 2020
} 
perdamaian dengan putusan yang adil bagi kedua belah pihak, namun apabila musyawarah tersebut tidak berhasil maka dilanjutkan ke jalur hukum formal.

Proses penerapan diversi terhadap anak yang berkonflik dengan hukum diawali dengan mediasi atau musyawarah sesuai dengan Qanun Aceh Nomor 9 Tahun 2008 tentang pembinaan kehidupan adat dan adat istiadat yaitu dengan mengumpulkan keluarga korban dan pelaku beserta pihak terkait untuk diselesaikan secara kekeluargaan, namun apabila upaya tersebut tidak berhasil maka dilanjutkan ke proses hukum sesuai dengan Undang- undang Nomor 11 Tahun 2012 Tentang Sistem Peradilan Pidana Anak, maka dilanjutkan dengan pelaksanaan diversi dimulai dari yang Pertama, polisi sebagai institusi formal ketika anak nakal pertama kali bersentuhan dengan sistem peradilan, yang juga akan menentukan apakah anak akan dibebaskan atau diproses lebih lanjut. Kedua, jaksa dan lembaga pembebasan bersyarat yang juga akan menentukan apakah anak akan dibebaskan atau diproses ke pengadilan anak. Ketiga, Pengadilan Anak, tahapan ketika anak akan ditempatkan dalam pilihan-pilihan, mulai dari dibebaskan sampai dimasukkan dalam institusi penghukuman.

Penerapan diversi dalam penyelesaian tindak pidana anak di kota Langsa sudah berjalan sesuai Undang Undang sistem peradilan anak, Akan tetapi pengadilan bukanlah satu-satunya institusi dalam menyelesaikan konflik, karena pihak-pihak yang berkonflik tidak selamanya menggunakan mekanisme penyelesaian pada badan peradilan. seperti penyelesaian anak yang berkonflik dengan hukum dengan jalur diluar pengadilan.

\section{B. Saran}

Perlu adanya pemberian pemahaman kepada masyarakat terkait penyelesaian masalah yang menimpa anak di bawah umur agar masyarakat lebih paham dan lebih sadar bahwa tidak semua tindak kejahatan harus diselsaikan secara hukum, serta perlu adanya penambahan jenis-jenis perkara di dalam qanun nomor 9 tahun 2008 seperti tindak kejahatan yang ancaman hukumannya di bawah 7 tahun sesuai dengan Undang-Undang Nomor 11 Tahun 2012, agar pemidanaan terhadap anak merupakan jalan terakhir dalam menyelesaikan masalah (ultimum remedium).

Perlu adanya pemberian pemahanan yang lebih kepada para penegak hukum yang terkait tentang tujuan dari diversi agar dapat memberikan masukan dan menyakinkan korban/keluarga korban agar masalah tersebut dapat terselesaikan dengan kesepakatan yang adil bagi kedua belah pihak tanpa harus dilanjutkan ke tingkat yang lebih tinggi.

Perlu evaluasi kembali Pelaksanaan upaya diversi di Pengadilan Negeri Langsa yang dianggap mubazir karena secara garis besar hanya pengulangan pada tingkat peradilan adat gampong, penyidikan dan penuntutan, sehingga bertentangan dengan asas peradilan cepat, sederhana dan biaya ringan. 


\section{DAFTAR PUSTAKA}

\section{A. Buku}

Hakim, Abdul Aziz, Negara Hukum dan Demokrasi Di Indonesia, Pustaka Pelajar, Yogyakarta, 2011

Mochtar, Akil, Pembalikan Beban Pembuktian Tindak Pidana Korupsi, Mahkamah Konstitusi, Jakarta, 2009

Herlina,Apong, dkk, Perlindungan Terhadap Anak Yang Berhadapan Dengan Hukum, Buku Saku Untuk Polisi, Unicef, Jakarta, 2014

Priyatno, Dwidja, Wajah Hukum Pidana Asas dan Perkembangan, Gramata Publishing, Bekasi, 2012

Friedman, Lawrence Meil, Law and Society; an Introductions, (Prencite-Hall Foundations of Modern Sociology Series, Englewood Cliffts), Standford University, New Jersey, 1979

Joni, Muhammad dan Zulchaina Z Tanamas, Aspek Perlindungan Anak DalamPerspektif Konvensi Hak Anak, PT Citra Aditya Bakti, Bandung, 1999

Majelis Adat Aceh, Pedoman Peradilan Adat di Aceh Untuk Peradilan Adat Yang Adil dan Akuntabel, 2008

Makarao, M. Taufik, Pengkajian Hukum Tentang Penerapan Restorative Justice Dalam Penyelesaian Tindak Pidana yang Dilakukan Oleh Anak-Anak, Badan Pembinaan Hukum Nasional Kementerian Hukum Dan HAM RI, Jakarta, 2013

Raharjo, Satjipto, Membedah hukum progresif, Penerbit Buku Kompas, Jakarta, 2007

Soekanto, Soerjono, Faktor-faktor Yang Mempengaruhi Penegakan Hukum, Raja Grafindo Persada, Jakarta, 2007

Mertokusumo, Sudikno, Mengenal Hukum, Liberty, Yogyakarta, 2005

Fajarini, Ulfah, Peranan Kearifan Lokal dalam Pendidikan Karakter, , Rineka Cipta, Jakarta, 2014

Friedman, W, Teori dan Filsafat Hukum: Telaah kritis atasi Teori-teori Hukum (susunan I), judul asli Legal Theory, penerjemah: Muhammad Arifin, Cetakan ke-2, PT Raja Grafindo Persada, Jakarta, 1993.

\section{B. Artikel Jurnal}

Isnatul Rahmi dan Riza nizarli, Penerapan Restorative Justice Dalam Penyelesaian Tindak Pidana Pencurian Oleh Anak dalam Perspektif Adat Aceh, Jurnal Law Syiah Kuala, Volume 4, 2020 
Volume 16, Nomor 1, Januari - Juni 2021

\section{Sumber Internet}

www.jimly.com/makalah/namafile/56/Penegakan_Hukum.pdf, diakses tanggal 22 November 2020.

\section{Peraturan Perundang-undangan}

Undang-Undang Nomor 11 Tahun 2012 tentang Sistem Peradilan Pidana Anak

Qanun Aceh Nomor 10 Tahun 2008 Tentang Lembaga Adat 